
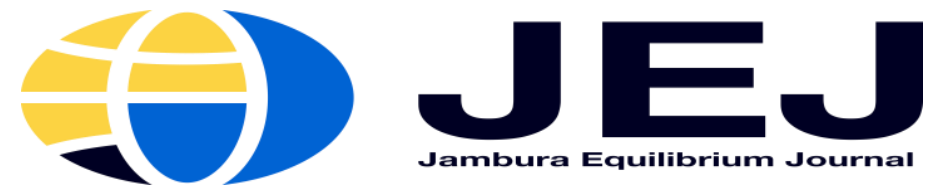

Volume 3. Issue 2. 2021

P-ISSN 2655-9110

E-ISSN 2656-0445

http://ejurnal.ung.ac.id/index.php/equij

\title{
Implementation of PSAK 71 in Indonesia: Mutual Fund Investment in Insurance Subsector Companies
}

\author{
Andy Kurniawan ${ }^{1}$, Amrie Firmansyah ${ }^{2}$ \\ Polytechnic of State Finance STAN, South Tangerang, Banten ${ }^{1,2}$
}

\begin{abstract}
Changes in financial accounting standards in Indonesia can result in additional costs that companies, including financial companies, must bear. This study aims to review the implementation of PSAK 71 in insurance companies in Indonesia related to mutual fund investment ownership. The method used in this study is a qualitative method with content analysis. The analysis was conducted with data and information on the financial statements for 2020 and 2019 of insurance sub-sector companies available on www.idx.co.id. A sampling of this study employed purposive sampling with a total sample that amounted to 26 observations. This study concludes that the implementation of PSAK 71 does not affect the measurement and value of mutual fund investments. It only has an impact on the classification of mutual fund investments in the company's financial statements. Also, this study finds that 4 out of 13 insurance companies have implemented a mutual fund investment classification according to PSAK 71 (2017). Insurance companies that have not implemented PSAK 71 (2017) are due to the company's policy that stipulates to apply PSAK 62 (2017), which allows insurance companies to postpone the implementation of PSAK 71 (2017).
\end{abstract}

Keywords: PSAK 71, Mutual Fund, Insurance Company

\section{INTRODUCTION}

Currently, the business world continues to experience development and intense competition to provide services to consumers, including the insurance business. The services obtained by the community with the existence of insurance businesses are widely beneficial both individually and organizationally. Insurance can be a form of self-protection from loss or financial risk due to specific events. Astanti (2015) stated that insurance is essential for Indonesia's economic stability and growth as a source of funding for economic growth to be spread as evenly as possible. Insurance can protect individuals or organizations against financial risk to anticipate unexpected events in the future (Yushita, 2017).

In fulfilling the benefit obligations to policyholders, insurance companies can invest in various types of financial assets. One of the investment assets that insurance companies choose is mutual funds. Based on Article 1 Number 27 of Law Number 8 of 1995 concerning the Capital Market, the definition of mutual funds is a forum used to collect funds from the investor community to be subsequently invested in Securities Portfolios by Investment Managers. Mutual funds are one of the 
financial asset investments chosen by insurance companies because they have minimal risk compared to other investments such as stocks or property. After all, there is no risk of losing value caused by natural disasters (Syailendra, n.d.). Mutual funds are an alternative to obtain competitive income so that investors with limited funds can diversify their investments and minimize risk (Putra \& Mawardi, 2016).

In recent years, mutual fund investment has increased significantly. In Canada, the number of open-ended mutual fund units increased from 1.16 trillion USD in 2018 to 1.4 trillion USD in 2019 (Researchandmarkets.com, 2020), while the number of mutual fund investors as of January 2020 in Indonesia was 1.84 million, which increased by 4.06 percent of the number of investors as of December 2019 (Santoso, 2020). The number of mutual fund units also increased in line with the increasing number of investors. Therefore, the Indonesian Financial Services Authority (OJK) confirmed that investment in mutual funds is still trusted by investors even though OJK has suspended mutual fund products from 37 Investment Manager companies in 2019 (Saragih, 2020).

In the context of accounting, the International Accounting Standard Board (IASB) has issued guidelines regarding financial instruments that replace IAS 39, namely IFRS 9 concerning financial instruments, which is effective on January 1,2018 . The issuance of IFRS 9 led to an adjustment of accounting standards in Indonesia. The Indonesian Institute of Accountants (IAI) has established a new accounting standard, namely PSAK 71 on Financial Instruments, which regulates financial reporting principles on company financial assets so that the information presented is relevant and valuable for users of financial statements. PSAK 71 adopted the provisions stipulated in IFRS 9 and became effective on January 1, 2020. PSAK 71 contains several changes to the previous accounting standard, namely PSAK 55 concerning Financial Instruments: Recognition and Measurement. PSAK 71 regulates several matters, including recognizing, derecognition, classification, and measurement of financial assets.

The change in accounting standards causes insurance companies to adjust and apply accounting standards to their financial assets following PSAK 71 . Companies need to review the classification and measurement of financial assets because PSAK 71 stipulates that the classification and measurement of financial assets are based on contractual cash flows and entity model business (IAI, 2016). In addition, the change in the classification of financial assets in PSAK 71 from 4 categories to 3 categories causes companies to need to make adjustments to their financial asset categories. Insurance companies apply PSAK 71 on financial assets, especially mutual funds, according to the conditions and circumstances of the company. The company may recognize and measure its financial assets based on amortized cost, fair value through other comprehensive income, or fair value through profit or loss. Therefore, research on financial assets, especially mutual funds, needs to be conducted to ensure that insurance companies recognize and measure their financial assets according to applicable accounting standards. Recognition and measurement of financial assets according to applicable accounting standards will produce financial reports that stakeholders can use to determine the company's performance, financial activities, and management of its financial assets.

Several studies have been conducted to discuss the implementation of 
accounting standards and corporate financial assets. Witjaksono (2017) concluded that there are fundamental differences in credit treatment between PSAK 55 and PSAK 71, especially in the formation of Allowance for Impairment Losses (CKPN) in banking companies. Arifullah and Firmansyah (2021) found that the implementation of PSAK 71 had an impact on reducing banking business capital but did not affect the company's ability to meet the capital adequacy ratio. Rizal and Shauki (2019) suggested that decision-making on the early application of PSAK 71 is dominated by coercive isomorphism conditions, namely mimetic and normative isomorphism. Suroso (2017) concluded that PSAK 71 has a negative impact on increasing CKPN in banking companies, so that reasonable preparation steps are needed from strategic, technical, and operational aspects. Novotny-Farkas (2016) found that IFRS 9 can affect banking policies in terms of investment due to the provision for loan losses. Low et al. (2019) concluded that under IFRS 9, investments are measured at fair value through the income statement.

Meanwhile, Suryani

stipulated that accounting standards that regulate the accounting treatment of mutual fund investments add a sense of security, assurance, and investor confidence to the mutual fund investments made. Insurance companies have not implemented accounting standards optimally so that the information in the company's financial statements provided to parties in need is not optimally used (Habiburahman et al., 2012). Agustine and Mahwiyah (2019) reviewed that PSAK 50 and PSAK 55 have been applied by the company to identify the debtor's ability to pay debts due based on the contract. Rahmadhani (2014) reviewed the impact of the implementation of PSAK 50, PSAK 55, and PSAK 60 on the provision for bank credit losses and stated that mutual funds are financial assets that are not classified as loans or receivables. Longgorung et al. (2015) concluded that banks had recognized financial assets following PSAK 60. Larasati and Supatmi (2014) concluded that bank financial assets classified as loans \& receivables have the most significant number of disclosures compared to other financial assets based on PSAK 50 and 60. Witjaksono (2018) concluded that the implementation of PSAK 71 to banking companies resulted in a different probability of default from the Basel accord in following movements or changes in economic conditions. Matoviany and Firmansyah (2021) concluded that PSAK 71 has been implemented by banking companies on bond investments and has no impact on the company's operational activities. The method employed for corporate CKPN in PSAK 71 is different from PSAK 55. PSAK 71 uses the expected credit loss method, which impacts the greater CKPN value (Ilat et al., 2020).

Based on previous research, the discussion of the implementation of PSAK 71 on mutual fund investment in insurance companies is still very rarely conducted. This study is different from previous studies conducted by Witjaksono (2017), Suroso (2017), Rizal and Shauki (2019), and Arifullah and Firmansyah (2021), which mainly discussed the impact of PSAK 71 (2017) implementation on CKPN for banking companies. In comparison, this study aims to review the implementation of PSAK 71 on financial assets, especially mutual fund investments in insurance companies, in terms of classification and measurement. This study is expected to provide information regarding changes in accounting standards for financial assets, especially mutual funds, and the implementation of PSAK 71 that insurance companies must carry out, considering that 
there are not many references that discuss in depth.

Also, this study is expected to contribute to the literature in financial accounting related to the implementation of PSAK 71 on financial assets, especially mutual funds carried out by financial service companies. In addition, this study can also provide improvements to OJK supervision of the activities of financial service companies so that they are carried out regularly, fairly, transparently, and accountably to protect the interests of the community. For IAI, this study is expected to improve financial accounting standard policies regarding disclosing and reporting financial assets to help realize one of the organization's missions, namely, good governance. For other companies, especially financial services companies other than the insurance sector, this study is expected to reference the implementation of PSAK 71 on their financial assets.

\section{METHODOLOGY}

The method employed in collecting data and information in this research is a qualitative method with content analysis techniques. The process of data analysis was carried out during data collection until the research was completed. The data employed in this study is secondary data in the form of data and information on financial statements for 2020 and 2019 of insurance sub-sector companies that were accessed through www.idx.co.id. In 2020, there are 16 insurance sub-sector companies listed on the Indonesia Stock Exchange. Of the 16 companies, 13 companies were selected based on their mutual fund investments in their financial assets.

Table 1 Research Sample

\begin{tabular}{lc}
\hline \multicolumn{1}{c}{ Criteria } & Amount \\
\hline Insurance companies listed on the Indonesia Stock Exchange & 16 \\
Number of companies that do not have mutual funds investment & 3 \\
Number of companies as research sample & 13 \\
Number of years of research & 2 \\
Total & 26 \\
\hline
\end{tabular}

Source: Processed

Table 2 List of Insurance Subsector Companies as Research Sample

\begin{tabular}{llll}
\hline No. & Code Name & Name & Category \\
\hline 1. & ABDA & PT Asuransi Bina Dana Arta Tbk & General Insurance \\
2. & AHAP & PT Asuransi Harta Aman Pratama Tbk & General Insurance \\
3. & ASBI & PT Asuransi Bintang Tbk & General Insurance \\
4. & ASDM & PT Asuransi Dayin Mitra Tbk & General Insurance \\
5. & ASMI & PT Asuransi Maximus Graha Persada & General Insurance \\
& & Tbk & \\
6. & JMAS & PT Asuransi Jiwa Syariah Jasa Mitra & Sharia Life Insurance \\
7. & LIFE & Abadi Tbk & \\
& & PT Asuransi Jiwa Sinarmas MSIG Tbk & Life Insurance, including \\
8. & LPGI & PT Lippo General Insurance Tbk & Sharia \\
9. & MREI & PT Maskapai Reasuransi Indonesia Tbk & Reinsurance
\end{tabular}


10. MTWI

11. PNIN

12. TUGU
PT Malacca Trust Wuwungan Insurance General Insurance Tbk

PT Paninvest Tbk

PT Asuransi Tugu Pratama Indonesia General Insurance Tbk

13. VINS PT Victoria Insurance Tbk
General Insurance

General Insurance

Source: Processed

RESULTS AND DISCUSSION

Accounting Analysis of Mutual Fund Investments in Insurance Subsector Companies
The companies need to adjust the classification and measurement of their financial assets following the provisions stipulated in PSAK 71 (2014). Table 3 shows a comparison of mutual funds based on PSAK 55 (2015) and PSAK 71 (2017).

Table 3 Comparison of Mutual Funds Based on PSAK 55 and PSAK 71

\begin{tabular}{lll}
\hline Mutual Funds & PSAK 55 (2015) & PSAK 71 (2017) \\
\hline Classification & $\begin{array}{l}\text { Not included in the } \\
\text { classification of loans and } \\
\text { receivables }\end{array}$ & $\begin{array}{l}\text { Financial assets are measured at fair } \\
\text { value through other comprehensive } \\
\text { income (FVTOCI) or fair value through } \\
\text { profit or loss (FVTPL) }\end{array}$ \\
$\begin{array}{ll}\text { Measurement } \\
\text { Gain or Loss }\end{array}$ & $\begin{array}{l}\text { Fair Value } \\
\text { The difference between fair value and transaction value }\end{array}$ \\
\hline
\end{tabular}

Source: Processed

The classification of financial assets by insurance companies previously used PSAK 55 (2015), but the enactment of PSAK 71 (2017) came into effect on January 1, 2020, replacing PSAK 55 (2015), causing changes in the accounting policies of insurance companies. The analysis of the implementation of PSAK 71 (2017) on insurance sub-sector companies listed on the Indonesia Stock Exchange is as follows:

\section{PT Asuransi Bina Dana Arta Tbk (ABDA)}

Based on the Notes to the Financial Statements (CaLK) of PT Asuransi Bina Arta Tbk and its subsidiaries dated December 31, 2020, the company explained that the new accounting standards did not cause substantial changes to the company's accounting policies and did not have a material impact on the company's financial statements, including PSAK 71 (2017). However, the company chose to apply the postponement of PSAK 71 (2017) following the provisions allowed in PSAK 62 (2017). The classification of financial assets employed in the 2020 financial statements is the same as the classification of financial assets in the 2019 financial statements according to PSAK 55 (2015); namely, financial assets are measured at fair value through profit or loss, held-tomaturity investments, loans and receivables, and financial assets available for sale.

The company's mutual fund investments are classified as financial 
assets determined to be measured at fair value through profit or loss in the trading group because they are acquired or held for resale shortly. In addition, the company also classifies mutual fund investments as available-for-sale financial assets. Mutual fund investments are recognized at their fair value upon initial recognition. The accumulated gain or loss arising from impairment of available-for-sale financial assets is recognized in the consolidated statements of profit or loss and other comprehensive income. In 2020, the company's total investment in mutual funds decreased by Rp. 134.433.980.,000 or $89.23 \%$, resulting in a comparison of the investment balance of mutual funds as described in the following table;

Table 1 ABDA's Mutual Funds Investment Balance in 2020 and 2019

\begin{tabular}{lcc}
\hline $\begin{array}{l}\text { Assets } \\
\text { Investment }\end{array}$ & $\begin{array}{c}\text { 31 December 2020 } \\
\text { (expressed in thousands of Rupiah) }\end{array}$ \\
\hline $\begin{array}{l}\text { Marketable Securities } \\
\quad \text { Mutual Funds - held for trading }\end{array}$ & - & 150.661 .922 \\
$\quad$ Mutual Funds - available for sale & 16.227 .942 & - \\
\hline
\end{tabular}
Source: Processed from ABDA's 2020 Financial Statements

\section{PT Asuransi Harta Aman Pratama Tbk}

Based on the CaLK of PT Asuransi Harta Aman Pratama Tbk dated December 31,2020 , the company stated that it is still implementing PSAK 55 (2015) to classify its financial assets. The classification of financial assets reflects the nature of the information and the fair value of the financial assets. The classification of financial assets is financial assets at fair value through profit or loss, loans, and receivables, held-to-maturity investments, or available-for-sale assets. At initial recognition, financial assets are recognized at fair value and can be evaluated on the classification of financial assets if necessary and allowed at the end of the financial period. The company assigns mutual fund investments in the classification of available-for-sale financial assets. In 2020, the company's total investment in mutual funds decreased by Rp11.352.474.589, or 33.60\%. According to the statement of financial position as of December 31, 2020, the comparison of the company's mutual fund investment balance is as follows.

Table 2 AHAP's Mutual Funds Investment Balance in 2020 and 2019

\begin{tabular}{lcc}
\hline Assets & $\begin{array}{c}\text { 31 December 2020 } \\
\text { (representated in Rupiah) }\end{array}$ & 31 December 2019 \\
\hline $\begin{array}{l}\text { Investment } \\
\text { Mutual Funds - available for sale }\end{array}$ & 22.433 .683 .023 & 33.786 .157 .612 \\
\hline Source: Processed from AHAP's 2020 Financial Statements
\end{tabular}

Source: Processed from AHAP's 2020 Financial Statements

\section{PT Asuransi Bintang Tbk (ASBI)}

Based on the CaLK of PT Asuransi Bintang Tbk dated December 31, 2020, it is stated that the company has suspended the application of PSAK 71 (2017) accounting standards based on the provisions of PSAK 62 (2017). The Company classifies financial assets based on the acquisition objective by considering the quoted prices of financial assets in an active market. 
Financial assets are measured at fair value at initial recognition by referencing the transaction price or the prevailing market price. The Company classifies financial assets into three categories: financial assets at fair value through profit or loss, loans and receivables, and available-for-sale financial assets. The company's mutual fund investments are classified as financial assets at fair value through profit or loss and are recorded in the consolidated statement of financial position. Total investment in the company's mutual funds decreased in 2020 by Rp1.637.949.000 or $7.03 \%$ compared to 2019. Table 6 illustrates the comparison of the company's mutual fund investment balance according to the consolidated statement of financial position as of December 31, 2020.

Table 3 ASBI's Mutual Funds Investment Balance in 2020 and 2019

\begin{tabular}{lcc}
\hline Assets & $\begin{array}{c}\text { 31 December 2020 } \\
\text { (expressed in thousands of Rupiah) }\end{array}$ & $\begin{array}{c}\text { 31 December 2019 } \\
\text { Investment } \\
\text { Mutual Funds }\end{array}$ \\
\hline
\end{tabular}

Source: Processed from ASBI's 2020 Financial Statements

\section{PT Asuransi Dayin Mitra Tbk (ASDM)}

Based on the CaLK of PT Asuransi Dayin Mitra Tbk dated December 31, 2020, the company chose to postpone the implementation of PSAK 71 (2017) following the amendments to PSAK 62 (2017) so that the company classifies its financial assets based on PSAK 55 (2015) the same as in 2019. Financial assets are classified into four categories: financial assets at fair value through profit or loss, loans and receivables, held-to-maturity financial assets, and available-for-sale financial assets. The Company classifies financial assets at initial recognition based on the acquisition objective and re- evaluates them at the reporting date if necessary and permitted.

Financial assets, including mutual fund investments, are measured at fair value based on quoted market prices prevailing at market closing at the end of the reporting year. According to market value based on net asset value, mutual fund investments are stated on the statement of financial position in the securities investment category. In 2020, the company's mutual fund investment decreased by Rp4.045.779.000 or $5.44 \%$ compared to 2019. The comparison of the investment balance of mutual funds according to the company's CaLK details as of December 31, 2020, is as follows.

Table 4 ASDM's Mutual Funds Investment Balance in 2020 and 2019

\begin{tabular}{lcc}
\hline $\begin{array}{l}\text { Assets } \\
\text { Investments }\end{array}$ & $\begin{array}{c}\text { 31 December 2020 } \\
\text { (expressed in thousands of Rupiah) }\end{array}$ \\
\hline $\begin{array}{l}\text { Third Parties Marketable Securities } \\
\text { Trading - Rupiah } \\
\quad \text { Mutual Funds }\end{array}$ & & \\
$\quad \begin{array}{l}\text { Trading - US Dollar } \\
\quad \text { Mutual Funds }\end{array}$ & 70.240 .775 & 66.200 .277 \\
Related Parties Marketable Securities & & 7.522 .528 \\
$\quad$ Trading - Rupiah & - & \\
\hline
\end{tabular}




\begin{tabular}{ccc}
\hline Mutual Funds & 97.300 & 661.049 \\
\hline
\end{tabular}

Source: Processed from ASDM's 2020 Financial Statements.

\section{PT Asuransi Maximus Graha Persada Tbk (ASMI)}

Based on the CaLK of PT Asuransi Maximus Graha Persada Tbk dated December 31, 2020, the company states that the existence of PSAK 71 (2017) does not have a significant impact on the company's financial statements. However, the company decided to postpone the application of PSAK 71 (2017) following the amendments to PSAK 62 (2017) so that the company's financial assets are classified according to PSAK 55 (2015); namely, financial assets are measured at fair value through profit or loss, loans and receivables, assets available-for-sale, and held-to-maturity investments.

The company's financial assets are measured at fair value at initial recognition based on transaction prices or prevailing market prices. The company's mutual fund investments are classified as financial assets at fair value through profit or loss in the trading group. In 2020, the company's total investment in mutual funds decreased by $\mathrm{Rp} 10.483 .475 .248$, or $7.31 \%$. The comparison of the investment balance of PT Asuransi Maximus Graha Persada Tbk mutual funds in 2020 and 2019 is as follows.

Table 5 ASMI's Mutual Funds Investment Balance in 2020 and 2019

\begin{tabular}{lcc}
\hline Assets & 31 December 2020 & 31 December 2019 \\
Investment & (representated in Rupiah) \\
\hline
\end{tabular}

\begin{tabular}{|c|c|c|}
\hline $\begin{array}{l}\text { Securities at fair value } \\
\text { through profit or loss }\end{array}$ & 132.934 .028 .245 & 143.417 .503 .493 \\
\hline
\end{tabular}

Source: Processed from ASMI's 2020 Financial Statements

\section{PT Asuransi Jiwa Syariah Jasa Mitra Abadi Tbk (JMAS)}

Based on the CaLK of PT Asuransi Jiwa Syariah Jasa Mitra Abadi Tbk dated December 31, 2020, the company is currently still evaluating the impact of implementing the new accounting standard PSAK 71 (2017) on the company's financial statements. In its statement of financial position, the company made changes to the classification of financial assets following PSAK 71 (2017), namely financial assets at amortized cost, financial assets at fair value through profit or loss, and financial assets at fair value through other comprehensive income (OCI). Financial assets are classified based on the objective of acquisition and consideration of quoted prices in an active market. Financial assets are measured at fair value at initial recognition, referring to the transaction price or the prevailing market price. At the end of the reporting period, the company assesses the possibility of impairment of financial assets. Impairment occurs when there is objective evidence that an event occurred after the initial recognition of the financial asset. 
Table 6 JMAS's Mutual Funds Investment Balance in 2020 and 2019

\begin{tabular}{|c|c|c|}
\hline Assets & $\begin{array}{c}31 \text { December } 2020 \\
\text { (PSAK 71) }\end{array}$ & $\begin{array}{c}31 \text { December } 2019 \\
\text { (PSAK 55) }\end{array}$ \\
\hline Financial Asset & (repres & Rupiah) \\
\hline $\begin{array}{l}\text { Available for Sale } \\
\text { Mutual Funds } \\
\text { at Fair Value through } \\
\text { Other Comprehensive } \\
\text { Income }\end{array}$ & 16.317 .528 .957 & 24.633 .717 .755 \\
\hline
\end{tabular}

Mutual fund investments are classified as financial assets at fair value through other comprehensive income (OCI) in the company's statement of financial position. This classification follows PSAK 71 (2017), which replaces PSAK 55 (2015) used in the previous year's financial statements. The company's total investment in mutual funds decreased by $\mathrm{Rp}$. $8,316,188,798$ or $33.76 \%$ compared to 2019, resulting in a comparison of the investment balance of mutual funds as shown in table 9.

\section{PT Asuransi Jiwa Sinarmas MSIG Tbk (LIFE)}

Based on the CaLK of PT Asuransi Jiwa Sinarmas MSIG Tbk and its subsidiaries dated December 31, 2020, the company stated that it chose to postpone PSAK 71 (2017) based on the amendments to PSAK 62 (2017). Financial assets are classified according to PSAK 55 (2014), which has been applied to the company's 2019 financial statements, namely financial assets at fair value through profit or loss, held-to-maturity investments, loans, and receivables, and available-for-sale financial assets. The company's mutual fund investments are classified as financial assets at fair value through profit or loss in the trading group. In 2020, the company's total investment in mutual funds increased by $\operatorname{Rp} 320.000 .000 .000 .000$ or $9.38 \%$ compared to 2019. The comparison of the investment balance of PT Asuransi Jiwa Sinarmas MSIG Tbk and its subsidiaries as of December 31, 2020, and December 31, 2019 , is as follows following.

Table 7 LIFE's Mutual Funds Investment Balance in 2020 and 2019

\begin{tabular}{lcc}
\hline Assets & 31 December 2020 & 31 December 2019 \\
Investment & (representated in Rupiah)
\end{tabular}

Securities at fair value through profit or loss

3.731 .687

3.411 .687

Mutual Funds

Source: Processed from LIFE's 2020 Financial Statements

\section{PT Lippo General Insurance Tbk (LPGI)}

Based on the CaLK of PT Lippo General Insurance Tbk and its subsidiaries as of December 31,2020, the company still classifies its financial assets following PSAK 55 (2015). The company determines the classification of financial assets at initial recognition and can be re-evaluated at the end of each financial year. The company's mutual fund investments are 
classified as financial assets at fair value through profit or loss and available-for-sale financial assets. Total investment in the company's mutual funds in 2020 increased by $\mathrm{Rp} 175.250 .885 .458$ or $96.25 \%$ compared to 2019. The comparison of the investment balance of the company's mutual funds according to the consolidated statement of financial position as of December 31, 2020, is as follows.

Table 8 LPGI's Mutual Funds Investment Balance in 2020 and 2019

\begin{tabular}{|c|c|c|}
\hline Assets & $\begin{array}{l}31 \text { December } \\
2020\end{array}$ & 31 December 2019 \\
\hline Investment & \multicolumn{2}{|c|}{ (representated in Rupiah) } \\
\hline $\begin{array}{l}\text { Marketable Securities - Trading } \\
\text { Mutual Funds } \\
\text { Marketable Securities - Available }\end{array}$ & 352.300 .159 .904 & 177.023.574.446 \\
\hline $\begin{array}{l}\text { for Sale } \\
\text { Mutual Funds }\end{array}$ & 5.027 .500 .000 & 5.053 .200 .000 \\
\hline
\end{tabular}

PT Airline Reinsurance Indonesia Tbk (MREI)

Based on the CaLK of PT Airline Reasuransi Indonesia Tbk dated December 31,2020 , the company chose an accounting policy to postpone the implementation of PSAK 71 (2017) on financial assets based on the amendments to PSAK 62 (2017). The classification of financial assets used by the company is the same as the previous year's financial statements referring to PSAK 55 (2015). Financial assets are measured at fair value at initial recognition. The company's mutual fund investments are divided into three classifications: available-for-sale financial assets, financial assets at fair value through profit or loss, and held-to-maturity financial assets. In 2020, the company's total investment in mutual funds decreased by Rp256.632.650.242 or $59.93 \%$ compared to 2019 , resulting in a comparison of the company's mutual fund investment balance as follows.

Table 9 MREI's Mutual Funds Investment Balance in 2020 and 2019

\begin{tabular}{|c|c|c|}
\hline $\begin{array}{l}\text { Assets } \\
\text { Investment - Securities }\end{array}$ & $\begin{array}{r}31 \text { December } 2020 \\
\text { (represen }\end{array}$ & $\begin{array}{l}31 \text { December } 2019 \\
\text { in Rupiah) }\end{array}$ \\
\hline $\begin{array}{l}\text { Mutual Funds Available for Sale - } \\
\text { Third Parties }\end{array}$ & 101.776 .975 .900 & 116.356 .935 .277 \\
\hline $\begin{array}{l}\text { Mutual Funds at Fair Value Through } \\
\text { Profit or Loss - Third Parties } \\
\text { Mutual Funds Held to Maturity - } \\
\text { Third Parties }\end{array}$ & $\begin{array}{c}69.729 .500 .572 \\
85.000 .000\end{array}$ & $\begin{array}{c}226.867 .191 .437 \\
85.000 .000\end{array}$ \\
\hline
\end{tabular}

Source: Processed from MREI's 2020 Financial Statements

PT Malacca Trust Wuwungan Insurance Tbk (MTWI)
Based on the CaLK of PT Malacca Trust Wuwungan Insurance Tbk and its subsidiaries dated December 31, 2020, the company established an accounting policy 
to apply PSAK 71 (2017) to classify its financial assets. The financial asset classifications are financial assets measured at amortized cost, financial assets measured at fair value through profit or loss, and financial assets measured at fair value in other comprehensive income (OCI) without a reclassification feature of cumulative gains and losses on derecognition. The company's financial assets classification is determined at initial recognition based on the contractual cash flow characteristics of the financial assets and the company's business model.

Financial assets that do not meet the results of the sole payment of principal and interest (SPPI) test will be measured at fair value through profit or loss regardless of the company's business model. Mutual fund investments owned by the company are classified as financial assets measured at fair value through profit or loss and recorded in the statement of financial position. Total investment in the company's mutual funds in 2020 increased by Rp5.280.289 or $4.73 \%$ compared to 2019 . The comparison of the investment balance of the company's mutual funds and subsidiaries as of December 31, 2020, is as follows.

Table 10 MTWI's Mutual Funds Investment Balance in 2020 and 2019

\begin{tabular}{lcc}
\hline Assets & 31 December 2020 & 31 December 2019 \\
Investment & (representated in Rupiah)
\end{tabular}

at Fair Value Through Profit

or Loss $\quad 116.880 .434 \quad 111.600 .145$

Mutual Funds

Source: Processed from MTWI's 2020 Financial Statements

\section{PT Paninvest Tbk (PNIN)}

Based on PT Paninvest Tbk's CaLK dated December 31, 2020, the company established an accounting policy to apply PSAK 71 (2017) to the company's financial assets. The company made changes to the classification according to the new accounting standards. The classification of financial assets is determined at initial recognition based on the company's business model and contractual cash flows.
Financial assets are classified as financial assets at amortized cost, financial assets at fair value through profit or loss, or other comprehensive income. Mutual fund investments are classified as financial assets at fair value through profit or loss. In 2020, the company's total investment in mutual funds increased by Rp182.112.000.000 or $7.28 \%$. The comparison of the investment balance of PT Paninvest Tbk and its subsidiaries as of December 31, 2020, is as follows.

Table 11 PNIN's Mutual Funds Investment Balance in 2020 and 2019

\begin{tabular}{lc}
\hline Assets & 31 December 2020 \\
Investment & (expressed in millions of Rupiah)
\end{tabular}

\begin{tabular}{l}
\hline Mutual Funds at Fair Value Through \\
\\
Profit or Loss \\
\hline Source: Processed from PNIN's 2020 Financial Statements
\end{tabular}

Source: Processed from PNIN's 2020 Financial Statements 


\section{PT Asuransi Tugu Pratama Indonesia Tbk (TUGU)}

Based on the CaLK of PT Asuransi Tugu Pratama Indonesia Tbk and its subsidiaries dated December 31, 2020, the company established a policy to postpone the application of PSAK 71 (2017) on financial assets so that PSAK 55 (2015) is still used in classifying the company's financial assets. The Company classifies financial assets into four categories: financial assets at fair value through profit or loss, loans and receivables, held-tomaturity financial assets, and available-for- sale financial assets. The company classifies mutual fund investments into three categories: financial assets measured at fair value through profit or loss, available-for-sale financial assets, and heldto-maturity financial assets.

In 2020, the company's total investment in mutual funds increased by Rp 203.947 .880 .000 or $26.23 \%$ compared to 2019. Table 15 illustrates the comparison of the investment balance of PT Asuransi Tugu Pratama Indonesia Tbk and its subsidiaries as of December 31, 2020, and December 31, 2019.

Table 12 TUGU's Mutual Funds Investment Balance in 2020 and 2019

\begin{tabular}{lcc}
\hline $\begin{array}{l}\text { Assets } \\
\text { Investment - Marketable Securities }\end{array}$ & $\begin{array}{c}\text { 31 December 2020 } \\
\text { (expressed in thousands of Rupiah) }\end{array}$ & $\begin{array}{l}\text { 31 December 2019 } \\
\text { Mutual Funds - Third Parties }\end{array} \quad$ \\
$\quad$ At Fair Value Through Profit or Loss & 236.448 .262 & 236.873 .867 \\
- Available for Sale & 416.348 .420 & 408.004 .655 \\
Mutual Funds - Related Parties & & \\
$\quad$ At Fair Value Through Profit or Loss & 198.830 .970 & 773.807 \\
- Available for Sale & 122.232 .623 & 121.260 .066 \\
$\quad$ Held to Maturity & 7.500 .000 & 10.500 .000 \\
\hline
\end{tabular}

Source: Processed from TUGU's 2020 Financial Statements

\section{PT Victoria Insurance Tbk (VINS)}

Based on the CaLK of PT Victoria Insurance Tbk, the company stated that it had implemented the new accounting standard PSAK 71 (2017) for its financial assets for the financial year starting January 1, 2020. PSAK 71 (2017) replaces almost all existing provisions in PSAK 55 (2015), including classifying and measuring financial assets. The implementation of PSAK 71 (2017) causes companies to need to adjust the classification of financial assets in the statement of financial position referring to the three predetermined categories, namely those measured at fair value through profit or loss, amortized cost, and measured at fair value through other comprehensive income. This classification of financial assets depends on the company's business model and the contractual terms of the cash flows of the financial assets. The company's mutual fund investments are valued at fair value, measured based on the latest quoted market prices published on 30 December 2020 and 30 December 2019. Investments in mutual funds are classified as financial assets measured at fair value through other comprehensive income. In 2020, the company's total investment in mutual funds increased by Rp19.688.406.085 or $2069.11 \%$ compared to 2019 . Table 16 illustrates the comparison of the investment balance of PT Victoria Insurance Tbk's 
mutual funds as of December 31, 2020, and

December 31, 2019.

Table 13 VINS's Mutual Funds Investment Balance in 2020 and 2019

\begin{tabular}{lcc}
\hline Assets & $\begin{array}{c}\text { 31 December 2020 } \\
\text { (PSAK 71) } \\
\text { (representated in Rupiah) }\end{array}$ & $\begin{array}{c}\text { 31 December 2019 } \\
\text { (PSAK 55) }\end{array}$ \\
\hline $\begin{array}{c}\text { Efek Tersedia untuk Dijual } \\
\text { Unit Penyertaan Reksa Dana }\end{array}$ & 20.639 .947 .746 & 951.541 .661 \\
\hline
\end{tabular}

Source: Processed from VINS's 2020 Financial Statements

Tabel 14 The Implementation of PSAK 71 in Insurance Subsector Companies in 2020

\begin{tabular}{lll}
\hline No. & Insurance Subsector Companies & Implementation of PSAK 71 (2017) \\
\hline 1. & PT Asuransi Bina Dana Arta Tbk & Postponement based on PSAK 62 (2017) \\
2. & PT Asuransi Harta Aman Pratama Tbk & Still applying PSAK 55 (2014) \\
3. & PT Asuransi Bintang Tbk & Postponement based on PSAK 62 (2017) \\
4. & PT Asuransi Dayin Mitra Tbk & Postponement based on PSAK 62 (2017) \\
5. & PT Asuransi Maximus Graha Persada Tbk & Postponement based on PSAK 62 (2017) \\
6. & PT Asuransi Jiwa Syariah Jasa Mitra & Has implemented PSAK 71 (2017) \\
& Abadi Tbk & \\
7. & PT Asuransi Jiwa Sinarmas MSIG Tbk & Postponement based on PSAK 62 (2017) \\
8. & PT Lippo General Insurance Tbk & Still applying PSAK 55 (2014) \\
9. & PT Maskapai Reasuransi Indonesia Tbk & Postponement based on PSAK 62 (2017) \\
10. & PT Malacca Trust Wuwungan Insurance & Has implemented PSAK 71 (2017) \\
& Tbk & \\
11. & PT Paninvest Tbk & Has implemented PSAK 71 (2017) \\
12. & PT Asuransi Tugu Pratama Indonesia Tbk & Still applying PSAK 55 (2014) \\
13. & PT Victoria Insurance Tbk & Has implemented PSAK 71 (2017) \\
\hline
\end{tabular}

Source: Processed

Table 15 Impact of the Implementation of PSAK 71 (2017) on Mutual Funds Investment in 2020

\begin{tabular}{lll}
\hline No. & Insurance Subsector Companies & Impact on Investment Value \\
\hline 1. & $\begin{array}{l}\text { PT Asuransi Jiwa Syariah Jasa Mitra } \\
\text { Abadi Tbk }\end{array}$ & $\begin{array}{l}\text { The implementation of PSAK 71 (2017) does } \\
\text { not affect the investment value of the } \\
\text { company's mutual funds. The existence of } \\
\text { gain or loss listed in the financial statements } \\
\text { 2. }\end{array} \quad \begin{array}{l}\text { PT Malacca Trust Wuwungand by a sale and purchase transaction } \\
\text { and/or the difference between the acquisition } \\
\text { price and the last fair value. }\end{array}$ \\
3. & $\begin{array}{l}\text { PT Paninvest Tbk } \\
\text { 4. PT Victoria Insurance Tbk }\end{array}$
\end{tabular}

Source: Processed

The accounting policy analysis discussion for mutual fund investments in each insurance company listed on the
Indonesia Stock Exchange can be summarized into information according to Table 17 and Table 18. 
Evaluation of the Impact of the Implementation of PSAK 71 on Mutual Fund Investment in Insurance Subsector Companies

Based on an analysis of the financial statements of insurance sub-sector companies listed on the Indonesia Stock Exchange, the results suggested that PSAK 71 (2017) has not been fully implemented by all insurance sub-sector companies with the condition that only 4 of the total 13 companies analyzed have implemented the classification of financial assets according to PSAK 71 (2017). However, 9 other companies have not implemented PSAK 71 (2017), so they still refer to the classification of financial assets according to PSAK 55 (2015). The existence of an amendment to PSAK 62 (2017) is the basis for not applying PSAK 71 (2017) to insurance companies. PSAK 62 (2017) is an accounting standard on insurance contracts that stipulates that insurance companies may delay or layered approaches in implementing PSAK 71 (2017). Companies that have never implemented PSAK 71 (2017) early and most of their business activities are related to insurance activities can apply a postponement of PSAK 71 (2017) to classify mutual fund investments. Insurance companies that meet the requirements and choose to postpone the PSAK 71 (2017) implementation will employ the previous accounting standard, namely PSAK 55 (2015), to classify the company's mutual fund investments. PSAK 62 (2017) provides directives that do not require insurance companies as insurers who choose to temporarily postpone PSAK 71 (2017) to apply PSAK 55 (2015) for the financial year period before January 1, 2022 (IAI, 2016). PSAK 62 (2017) is the main factor that causes not all insurance companies analyzed to apply the classification of financial assets based on PSAK 71 (2017). The option to postpone the application of PSAK 71 (2017) listed in PSAK 62 (2017) makes insurance companies prefer to apply the provisions contained in PSAK 62 (2017) because these accounting standards are made explicitly for companies whose business activities are mostly related to insurance.

In general, the implementation of PSAK 71 (2017) only impacts company policies to adjust the classification of their mutual fund investments. PSAK 71 (2017) implementation does not affect the investment value of the insurance subsector mutual fund companies. The company applies a new classification with the exact measurement of mutual fund investments as before. Mutual fund investments owned by the company are measured at fair value at the time of initial recognition, referring to quoted prices in an active market.

The implementation of PSAK 71 (2017) on mutual fund investments encourages companies to simplify the mutual fund investment category in the company's financial statements to be more concise. The presentation of accounts in a more concise financial report impacts the grouping of mutual fund investments that is clearer and more information so that the information conveyed does not confuse users of financial statements. The simplification of the mutual fund investment category based on PSAK 71 (2017) can be seen from the presentation in the company's financial statements, which are divided into two categories, namely financial assets measured at fair value through profit or loss or measured at fair value through other comprehensive income (OCI). The classification in PSAK 71 (2017) is different from the classification of financial assets in PSAK 55 (2015), which was previously applicable. According to PSAK 55 (2015), mutual fund investments are divided into three categories: financial assets at fair value through profit or loss, 
held-to-maturity financial assets, or available-for-sale financial assets.

Based on the explanation above, the implementation of PSAK 71 (2017) on mutual fund investments only impacts presenting a more concise classification in the financial statements of insurance companies. The implementation has a different impact on other financial sector companies. It makes financial companies classify financial assets and has more influence on aspects of the formation of Allowance for Impairment Losses (CKPN). Witjaksono (2017) stated that the different methods used in PSAK 71 (2017) affect the formation of CKPN for financial companies. PSAK 71 (2017) uses the expected credit loss method, while PSAK 55 (2015) uses the loss incurred method. The difference in methods causes financial companies to provide a more considerable reserve value for credit than before. The expected credit loss method also aims to anticipate the future (forward-looking) in assessing the amount, timing, and future cash flows of banking companies. In addition, the implementation of PSAK 71 (2017) has an impact on decreasing the capital of financial companies, although it does not affect the ability to meet the minimum Capital Adequacy Ratio (Arifullah \& Firmansyah, 2021).

\section{CONCLUSION}

The implementation of PSAK 71 (2017) on mutual fund investments in insurance subsector companies does not affect the measurement and value of mutual fund investments. It only has an impact on the classification of mutual fund investments in the company's financial statements. The classification of mutual fund investments based on PSAK 71 (2017) is divided into financial assets measured at fair value through profit or loss or measured at fair value through other comprehensive income. The analysis results suggest that 4 out of 13 insurance companies have implemented a mutual fund investment classification according to PSAK 71 (2017). Insurance companies that have not implemented PSAK 71 (2017) are due to the company's policy that stipulates to apply PSAK 62 (2017), which allows insurance companies to postpone the application of PSAK 71 (2017).

The limitation of this study is that the discussion only employs the content analysis method. This method has the disadvantage that it only sees and analyzes information that is already visible and available so that there is a possibility of not getting the implicit information in depth. Future research is expected to use data and information on financial assets from sectors and sub-sectors other than insurance to produce a more comprehensive comparison. In addition, it is expected that future research will employ financial report data on the Indonesia Stock Exchange page and online media information and employs interviews with appropriate practitioners so that the results of the discussion obtained become more argumentative. In general, the financial statements of insurance companies have been presented quite well. However, the company should explain the changes in accounting policies applied by the company in the notes to its financial statements to make it easier for financial statements users.

\section{REFERENCES}

Agustine, R., \& Mahwiyah. (2019). Analisis Penerapan PSAK No.50 dan PSAK No.55 Atas Impairment Piutang Pada PT. Pelangi Cakrawala Losarang. Proseding Seminar Nasional Akuntansi, 2(1), 1-11.

Arifullah, M. N., \& Firmansyah, A. (2021). Pencadangan Piutang Pada 
Perusahaan Sub-Sektor Perbankan di Indonesia: Implementasi Penerapan PSAK 71. Jurnal Kajian Akuntansi Dan Bisnis Terkini, 2(1), 122-142.

Astanti, D. I. (2015). Good Corporate Governance pada Perusahaan Asuransi Edisi Revisi. In Perpustakaan Nasional RI: Katalog dalam Terbitan (KDT). Semarang University Press. www.pnm.co.id

Habiburahman, Jevilie, \& Riswan. (2012). Aplikasi PSAK No.28 dalam Kaitannya dengan Penyajian Laporan Keuangan Asuransi Jiwa. Jurnal Akuntansi Dan Keuangan, 3(1), 55-68. https://doi.org/http://dx.doi.org/10. 36448/jak.v3i1.219

Hasbiyah, W. (2020). Reksadana Dalam Persfektif Ekonomi Syariah. Jurnal Al-Hikmah, 8(10), 17-26.

Ilat, V., Sabijono, H., \& Rondonuwu, S. (2020). Evaluasi Penerapan PSAK 71 Mengenai Instrumen Keuangan pada PT. Sarana Sulut Ventura Manado. Jurnal Riset Akuntansi, 15(3), 514-520. https://doi.org/10.32400/gc.15.3.30 178.2020

Kusumawati, R. (2016). Analisis Kinerja Reksadana Saham Konvensional dan Reksadana Saham Syariah dengan Menggunakan Metode Sharpe. Journal Info Artha, 4(7), 151-170.

https://doi.org/https://doi.org/10.31 092/jia.v4i4.57

Larasati, A., \& Supatmi. (2014). Pengungkapan Informasi Aset Keuangan dan Impairment-nya di Perbankan Menurut PSAK 50 dan 60. Seminar Nasional Dan Call for Paper (Sancall 2014): Research Methods and Organizational Studies, 50(07), 296-306. http://hdl.handle.net/11617/4650
Longgorung, L. C., Pangemanan, S. S., \& Pusung, R. J. (2015). Pengungkapan Informasi Aset Keuangan Menurut PSAK 60 pada PT. Bank Rakyat Indonesia (Persero) Tbk. Jurnal EMBA, 3(1), 524-533.

Löw, E., Schmidt, E. L., \& Thiel, L. F. (2019). Accounting for Financial Instruments under IFRS 9 - FirstTime Application Effects on European Banks' Balance Sheet. European Banking Institute Working Paper Series, 48(10), 1102.

https://doi.org/10.2139/ssrn.346229 9

Matoviany, M. A., \& Firmansyah, A. (2021). Kepemilikan Investasi Obligasi Perusahaan Perbankan di Indonesia: Dampak Penerapan PSAK 71. Jurnal Financial and Tax, 1(1), 11-32.

Novotny-Farkas, Z. (2016). The Interaction of the IFRS 9 Expected Loss Approach with Supervisory Rules and Implications for Financial Stability. Accounting in Europe, 13(9), 197-227. https://doi.org/10.1080/17449480.2 016.1210180

Peraturan Otoritas Jasa Keuangan Nomor 19/POJK.04/2015 tentang Penerbitan dan Persyaratan Reksa Dana Syariah

Peraturan Otoritas Jasa Keuangan Nomor 47/POJK.04/2015 tentang Pedoman Pengumuman Harian Nilai Aktiva Bersih Reksa Dana Terbuka

Peraturan Otoritas Jasa Keuangan Nomor 49/POJK.04/2015 tentang Reksa Dana Berbentuk Kontrak Investasi Kolektif yang Unit Penyertaannya Diperdagangkan di Bursa Efek

Peraturan Otoritas Jasa Keuangan Nomor 23/POJK.04/2016 tentang Reksa Dana Berbentuk Kontrak Investasi Kolektif 
Peraturan Otoritas Jasa Keuangan Nomor 32/POJK.04/2017 tentang Pedoman Kontrak Pengelolaan Reksa Dana Berbentuk Perseroan

Peraturan Otoritas Jasa Keuangan Nomor 33/POJK.04/2017 tentang Pedoman Pengelolaan Reksa Dana Berbentuk Perseroan

Putra, B. P. B., \& Mawardi, I. (2016). Perbandingan Kinerja Reksadana Syariah di Indonesia Menggunakan Metode SHARPE (Studi Kasus Reksadana Syariah Saham, Reksadana Syariah Pendapatan Tetap dan Reksadana Syariah Campuran periode 2012-2014). Jurnal Ekonomi Syariah Teori Dan Terapan, 3(9), 683-698.

Qamruzzaman. (2014). Comparative Study on Performance Evaluation of Mutual Fund Schemes in Bangladesh: An Analysis of Monthly Returns. Journal of Business Studies Quarterly, 5(4), 190.

Rahmadhani, S. (2014). Dampak Penerapan PSAK 50, PSAK 55 dan PSAK 60 (Revisi) pada Penyisihan Kerugian Kredit Perbankan. Jurnal Ilmu Manajemen Dan Akuntansi Terapan (JIMAT), 5(5), 130-143.

Researchandmarkets.com. (2020). North America mutual fund industry | growth, trends, and forecast (20202025). Research and Markets. https://www.researchandmarkets.co m/reports/5177313/north-americamutual-fund-industrygrowth?utm_source=BW\&utm_me dium $=$ PressRelease \&utm $c$ code $=\mathrm{n} 9$ 2m4w\&utm_campaign $=1472410+-$ + North+America+Mutual+Fund+In dustry+Report+2020+\%7c+Growth $\% 2 \mathrm{c}+$ Trends $\% 2 \mathrm{c}+$ and + Forecast+to $+2025 \& u t m \_$exec $=$chdo54prd

Rizal, A. P., \& Shauki, E. R. (2019). Motif dan Kendala Bank Melakukan
Implementasi Dini PSAK No. 71 Terhadap CKPN Kredit (Motive and Obstacle Bank As Early Adopters of PSAK No. 71 for Allowance for Impairment Losses (CKPN) of Loan). Jurnal Akuntansi Dan Keuangan Indonesia, 16(1), 83-107.

http://jaki.ui.ac.id/index.php/home/ article/view/1394

Santoso, W. (28 Februari 2020). Ketua DK OJK, wimboh $s$ : jumlah investor reksadana januari 2020 tembus 1,84 juta. Bareksa. https://www.bareksa.com/berita/rek sa-dana/2020-02-28/ketua-dk-ojkwimboh-s-jumlah-investorreksadana-januari-2020-tembus184-juta

Saragih, H. P. (24 Februari 2020). Meski 'digoyang' kasus, investor reksa dana bertambah lho. CBNC Indonesia.

https://www.cnbcindonesia.com/m arket/20200224095025-17139951/meski-digoyang-kasusinvestor-reksa-dana-bertambah-lho

Suroso. (2017). Penerapan PSAK 71 dan Dampaknya Terhadap Kewajiban Penyediaan Modal Minimum Bank. Jurnal Bina Akuntansi, 4(2), 57165. https://wiyatamandala.ejournal.id/JBA/article/view/31/30

Suryani, A. (2009). Akuntansi Reksadana Prinsip Standar Akuntansi Keuangan (PSAK) No. 49. Jurnal Ilmiah Universitas Batanghari Jambi, 9(2), 1-6. https://media.neliti.com/media/publ ications/225581-akuntansireksadana-prinsip-standar-akunf9a55849.pdf

Syailendra Capital. (n.d). Perbandingan reksa dana vs properti. Syailendra Capital. https://syailendracapital.com/penge nalan-reksadana/perbandingan- 
reksa-dana-vs-properti

Undang-Undang Republik Indonesia Nomor 8 Tahun 1995 tentang Pasar Modal

Witjaksono, A. (2017). Dampak ED PSAK 71 Intrumen Keuangan Terhadap Pedoman Akuntansi Perbankan Terkait Kredit. Jurnal Online Insan Akuntan, 2(1), 35-48. https://doi.org/10.5281/zenodo.336 8520

Witjaksono, A. (2018). Perbandingan

Perlakuan Akuntansi Kredit
Menurut PSAK 55, PSAK 71, dan Basel pada Bank Umum. Jurnal Online Insan Akuntan, 3(2), 111120.

https://doi.org/10.5281/zenodo.336 8478

Yushita, A. N. (2017). Pentingnya Literasi Keuangan Bagi Pengelolaan Keuangan Pribadi. Jurnal Nominal, 6(1), 1-26. https://doi.org/10.21831/nominal.v6i1 .1433 